\title{
CLOUD POINT EXTRACTION FOR THE DETERMINATION OF TRACE COPPER(II) IN ENVIRONMENTAL SAMPLES USING A NEW SYNTHESIZED REAGENT AND FLAME ATOMIC ABSORPTION SPECTROMETRY
}

\author{
Zeynep Yurtman-Gündüzi1, Oya Aydın-Urucu1 ${ }^{*}$, Ece Kök-Yetimoğlu', Hayati Filik² \\ ${ }^{1}$ Department of Chemistry, Faculty of Science and Letters, \\ University of Marmara, Istanbul, 34722, Turkey \\ ${ }^{2}$ Department of Chemistry, Faculty of Engineering, \\ University of Istanbul, Istanbul, 34320, Turkey \\ oaydinurucu@marmara.edu.tr
}

\begin{abstract}
Cloud point extraction for the determination of copper(II) is proposed after the formation of a complex with sulfapyridylazo resorcinol (SPAR) and later measurement by flame atomic absorption spectrometry (FAAS) using Triton X-100 as a surfactant. The surfactant-rich phase was diluted with nitric acid in methanol, prior to FAAS measurement. Analytical parameters including $\mathrm{pH}$, concentration of the chelating agent and surfactant, equilibration temperature and time were optimized. The effects of matrix ions on the recovery of copper ions were also studied. A detection limit of $1.64 \mu \mathrm{g} \mathrm{l}^{-1}$ along with an enrichment factor of 31 for $\mathrm{Cu}$ were achieved. The method was successfully applied to the determination of copper in tap water, stream water, rain water and a standard reference material.
\end{abstract}

Keywords: cloud point extraction; copper(II); FAAS; preconcentration; triton X-100

\section{ЕКСТРАКЦИЈА НА ТЕМПЕРАТУРА НА ЗАМАТУВАЊЕ ЗА ОПРЕДЕЛУВАњЕ ТРАГИ НА БАКАР(ІІ) ВО ПРИМЕРОЦИ ОД ЖИВОТНАТА СРЕДИНА СО НОВОСИНТЕТИЗИРАН РЕАГЕНС И СО ПЛАМЕНА АТОМСКА АПСОРПЦИОНА СПЕКТРОМЕТРИЈА}

Предложен е метод за определување на траги од бакар(II) со екстракција на температура на заматување (анг. cloud point extraction) по образување на комплекс со сулфапиридилазо-резорцинол (SPAR). Потоа беше извршена анализа со пламена атомска апсорпциона спектрометрија, FAAS (од анг. flame atomic absorption spectrometry) со детергент Triton X-100. Пред определувањето co FAAS, фазата богата со детергент беше разредувана со азотна киселина во метанол. Беа оптимизирани аналитичките параметри на методот, вклучувајќ ги рН, концентрацијата на реагенсот-хелат и детергентот, рамнотежната температура и времето. Исто така беше испитувано влијанието на ефектот на јоните во матриксот на аналитичкиот принос на методот. При определувањето беше постигната граница на детекција од $1,64 \mu \mathrm{g} 1^{-1}$ со фактор на збогатување 31 . Методот беше успешно применет при анализа на вода од чешма, дождовница, истечна вода и стандарден референтен материјал.

Клучни зборови: екстракција на температура на заматување, СР екстракција; бакар(II), FAAS; преконцентрација; triton X-100. 


\section{INTRODUCTION}

Copper has attracted a great deal of attention because of its uses in metallurgy and the chemical industry. Moreover, copper is an essential element not only for humans but also for all other living beings. It is an essential constituent of about thirty enzymes and glycoproteins and it is required for the synthesis of hemoglobin and for some biological processes. Dissolved, reactive copper is toxic to marine plants and animals. Free ionic copper at a concentration as low as $0.3 \mu \mathrm{g} \mathrm{l}^{-1}$ decreases production in several species of oceanic phytoplankton. However, levels of copper often exceed optimum values and thereby cause toxicity. For this reason, the determination of the precise amount of copper in natural water and biological samples is very important $[2,3]$.

There are many techniques which have been used for the direct determination of copper at low concentrations, for example spectrophotometry, voltammetry, inductively coupled plasma optical emission spectrometry (ICP-OES), electrothermal atomic absorption spectrometry (ETAAS), X-ray fluorescence (XRF), flame atomic absorption spectrometry (FAAS) and inductively coupled plasma-mass spectrometry (ICP-MS), among others. Flame atomic absorption spectrometry is generally used for the determination of trace metals because of the simplicity of the process and low instrument and operation costs. However, due to the presence of $\mathrm{Cu}$ in environmental samples at low levels, a preconcentration step prior to atomic absorption spectrometric determination is usually necessary in order to reach an appropriate level of sensitivity. There are several preconcentration and separation techniques for the determination of $\mathrm{Cu}(\mathrm{II})$, such as liquid-liquid extraction (LLE), ion-exchange techniques and solid phase extraction (SPE) with various adsorbents. The traditional liquid-liquid extraction and other conventional separation methods are time-consuming and labor-intensive approaches, besides requiring relatively large amounts of high-purity and frequently toxic solvents, which have to be disposed of properly. Cloud point extraction (CPE) is an attractive technique to conventional liquid-liquid extraction. This method was chosen because of facility, low price, high efficiency and lower toxicity [4-6]. The metal-chelate complexes formed in micellar systems are more stable than those formed in the absence of micelles. The use of CPE has affected significant attention in the last few years, as it possesses a great capacity to concentrate a wide variety of toxic elements with good recovery and high preconcentration factors. Several reports have been published on the preconcentration of copper by the CPE method. In all mentioned studies, copper has been preconcentrated by the CPE method after the formation of sparingly water-soluble complexes with a suitable chelating agent such as 8-hydroxyquinoline (Oxine), diethyldithiocarbamate (DDTC), 1-(2-pyridylazo)2-naphthol (PAN), 1-(2-thiazolylazo)-2-naphthol (TAN) and 4-(2-pyridylazo)resorcinol (PAR), 4-(2'-thiazolylazo)-resorcinol (TAR), 2-(2-thiazolylazo)-p-cresol (TAC), 2-(2-thiazo lylazo)-4-methoxyphenol (TAMP) and others [7-13]. The CP of non-ionic surfactants can be conveniently decreased or increased by the presence of different additives (i.e., organic and inorganic additives), thus providing a way to use non-ionic surfactants under various conditions [14]. In addition, generally, inorganic salts like $\mathrm{KCl}, \mathrm{KNO}_{3}, \mathrm{NaCl}$, etc., are often used for promoting phase separation [15-17], and it has been observed that the presence of electrolytes decreases the cloud point (salting-out effect), resulting in low extraction efficiency. The lower cloud point extraction efficiency is attributed to electrolytes promoting dehydration of the poly(oxyethylene) chains [18]. According to Komaromy-Hiller et al. [19], the salting-out phenomenon is directly related to the desorption of ions to the hydrophilic parts of the micelles, increasing interactions between micelles and consequently leading to the precipitation of surfactant molecules. Many organic additives 
affect the CP temperature of micellar solutions of surfactants and are reported in the literature [14-20].

In this study, we aimed to develop a CPE method to determine the $\mathrm{Cu}$ (II) concentration in an aqueous sample by use of a non-ionic surfactant (Triton X-100 plus phenol) and sulfapyridylazo resorcin (SPAR) as the chelating agent. After phase separation, the surfactantrich phase was diluted with a methanol solution containing $0.1 \mathrm{M} \mathrm{HNO}_{3}$ and the copper concentrations of samples were determined by flame atomic absorption spectrometry (FAAS).

The main factors affecting the formation of a complex and extraction steps, such as $\mathrm{pH}$, SPAR concentration, TritonX-100 concentration, phenol concentration, equilibration temperature and time were optimized.

\section{EXPERIMENTAL}

\subsection{Materials}

The non-ionic surfactant Triton X-100 (Merck, Darmstadt, Germany) was used without further purification. The copper(II) ion standard solution was prepared by dissolving in distilled water appropriate amounts of a chloride salt of copper(II) ions (Merck, Darmstadt, Germany). A solution of SPAR was prepared by dissolving this reagent in an ultra-pure distilled water-1,4-dioxane (Merck, Darmstadt, Germany) mixture (1:1). Certified reference material (SPS WW1 Batch 109) was purchased from Spectrapura Standards AS (Oslo, Norway). All other reagents were of analytical reagent grade and all solutions were prepared in ultrapure distilled water.

A flame atomic absorption spectrometer of the Analytik Jena Instruments model AG ZEEnit 700 (Germany) equipped with air acetylene flame was used for absorbance measurements at $324.8 \mathrm{~nm}$ according to instrument instructions. A thermostated water bath (Nüve Water Bath Type NB9, Turkey) was used for CPE experiments and phase separation was performed using a centrifuge Bench-top Centrifuge Type NF400 (Turkey) in $50 \mathrm{ml}$ centrifuge tubes. A WTW inoLab $\mathrm{pH}$ 720-pH meter (Germany) was also used for $\mathrm{pH}$ measurements.

\subsection{Synthesis of sulfapyridylazo resorcinol}

A preparation procedure was described below for the preparation of sulfapyridylazo resorcinol. Six mmol of sulfapyridine in water was added in concentrated $\mathrm{HCl}$ and 6.1 mmol sodium nitrite in water at $0-5{ }^{\circ} \mathrm{C}$. For coupling, $6 \mathrm{mmol}$ of resorcinol was dissolved $7.2 \mathrm{ml}, 10 \% \mathrm{NaOH}$ and then was cooled to at $0-5{ }^{\circ} \mathrm{C}$. This solution was added drop by drop into the diazotized solution with vigorous stirring. The mixture was allowed to stand for $20 \mathrm{~min}$. in refrigerator at $0-5{ }^{\circ} \mathrm{C}$. The product was filtered and washed with distilled water. The reagent was purified by recrystallization in a mixture of ethanol and water $(50 \% \mathrm{~V} / \mathrm{V})$. The yield was found $67 \%$.

The IR spectrum of the dried product showed bands in the region ranging from 1630 to $1575 \mathrm{~cm}^{-1}, 1400 \pm 40 \mathrm{~cm}^{-1}$ corresponding to 3567(OH), 2932(-NH-), 1644(-N=N-), 1364 (R$\left.\mathrm{SO}_{2}-\mathrm{NH}\right), 652\left(-\mathrm{CH}_{2}-\mathrm{S}-\mathrm{CH}_{2}-\right)$. Scheme 1 shows a proposed structure for SPAR.

${ }^{1} \mathrm{H}$ NMR (400MHz, DMSO- $\left.d_{6}, \delta\right): 8.05$ $\left(\mathrm{H}_{\mathrm{d}}, \mathrm{d}, 2 \mathrm{H}\right), 6.87\left(\mathrm{H}_{\mathrm{e}}, \mathrm{d}, 2 \mathrm{H}\right), 7.25\left(\mathrm{H}_{\mathrm{f}}, \mathrm{s}, 2 \mathrm{H}\right)$, $7.70\left(\mathrm{H}_{\mathrm{g}}, \mathrm{s}, 1 \mathrm{H}\right), 7.90-7.94\left(\mathrm{H}_{\mathrm{h}}, \mathrm{m}, 3 \mathrm{H}\right), 7.99\left(\mathrm{H}_{\mathrm{h}}\right.$, $\mathrm{d}, 1 \mathrm{H}), 6.54\left(\mathrm{H}_{\mathrm{i}}, \mathrm{d}, 1 \mathrm{H}\right), 8.18\left(\mathrm{H}_{\mathrm{a}}, \mathrm{d}, 1 \mathrm{H}\right), 12.20$ $\left(\mathrm{H}_{c}, \mathrm{~s}, 1 \mathrm{H}\right)$; MS: $m / z=64,77,107,351(\mathrm{M}-18)$.

From the elemental analysis, the composition of $\mathrm{C}_{17} \mathrm{H}_{14} \mathrm{~N}_{4} \mathrm{O}_{4} \mathrm{~S}$ was found $(w / \%)$ : C 54.70, H 3.25, N 14.89, S 7.73; found: C 55.12, H 3.80, N 15.12, S 8.60. 


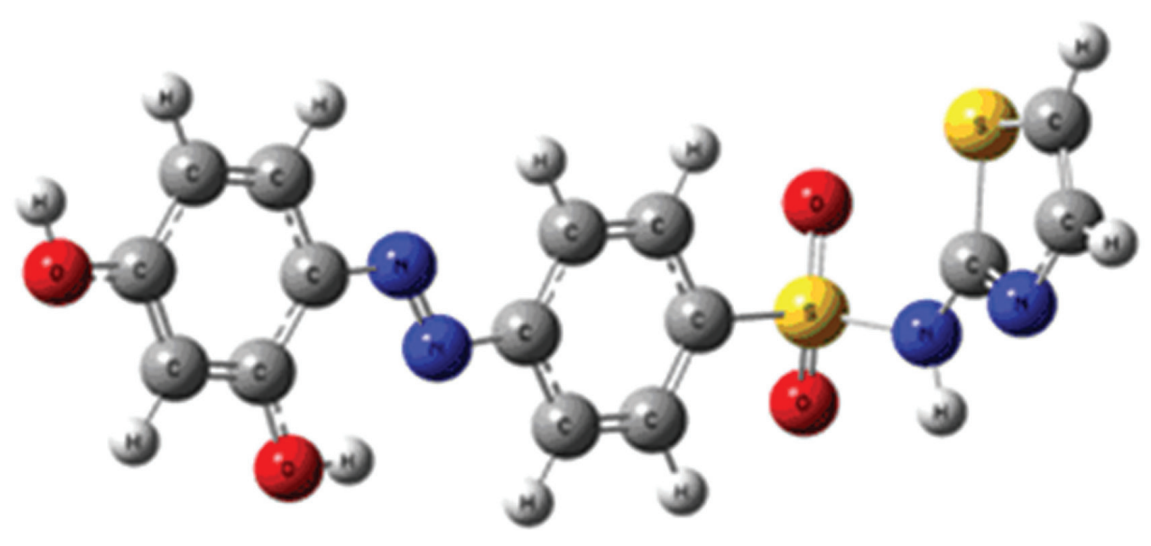

Scheme 1. Chemical structure of sulfapyridylazo resorcinol (SPAR)

\subsection{Procedure}

A typical cloud point extraction procedure requires following steps: a $50 \mathrm{ml}$ sample containing the analyte, $1.6 \mathrm{ml}$ of $5 \%(w / v)$ Triton $\mathrm{X}-100$ and $1.4 \mathrm{ml}$ of $5.0 \times 10^{-4} \mathrm{~mol} \mathrm{l}^{-1}$ SPAR was adjusted to $\mathrm{pH} 8.0$ with the addition of a borax buffer solution $(10 \mathrm{ml})$ and $6 \mathrm{ml}$ of a $5 \%(w / v)$ phenol solution, then placed into a centrifuge tube. Next, the mixture was heated in a thermostated water bath at $40{ }^{\circ} \mathrm{C}$ for $20 \mathrm{~min}$. Separation of the two phases was achieved by centrifugation for $15 \mathrm{~min}$ at $3500 \mathrm{rpm}$. The phases were cooled in an ice bath in order to increase the viscosity of the surfactant-rich phase. The aqueous phase was then decanted by inverting the tube. Later, in order to reduce the viscosity of the micellar phase and to promote its homogenization, $0.4 \mathrm{ml}$ of an acidified methanol solution containing 0.1 mol $1^{-1} \mathrm{HNO}_{3}$ was added to the surfactant-rich phase. The final solution $(1 \mathrm{ml})$ was introduced into the FAAS by conventional aspiration.

\subsection{Analysis of water samples}

Real samples of stream, rain and tap water were collected in Istanbul, Turkey. They were stored in glassware bottles and acidified for preservation. Before the CPE procedure, all the water samples were filtered through a $0.45 \mu \mathrm{m}$ pore size membrane filter to remove suspended particulate matter and then stored in a refrigerator.
Aliquots of water samples were subjected to the CPE methodology as described above.

\section{RESULTS AND DISCUSSION}

\subsection{Formation of the complex}

The solubility of SPAR was tested and it was found that the reagent is soluble in methanol, 1,4-dioxane, chloroform, acetone, and partly soluble in water and dichloromethane. SPAR has a good capacity for $\mathrm{Cu}^{2+}$ ion complexation, and forms a brown complex. The molar ratio of copper to STAR in the complex was found to be $1: 1$.

\section{Effect of $p H$}

The extraction of metal ions by the CPE method involves the formation of a metalchelate with sufficient hydrophobicity to be extracted into the small volume of the surfactantrich phase. The $\mathrm{pH}$ plays a unique role in metalchelate formation and in subsequent cloud point extraction yield [21]. Therefore, $\mathrm{pH}$ was the first parameter evaluated for its effect on the determination of copper ions. Figure 1 shows the effect of $\mathrm{pH}$ in the range of 6.0-9.0 on the extraction of the $\mathrm{Cu}(\mathrm{II})$ complex. Quantitative extraction efficiency was achieved at $\mathrm{pH}$ 8.0. For this reason, $\mathrm{pH} 8.0$ was used for the subsequent work. 


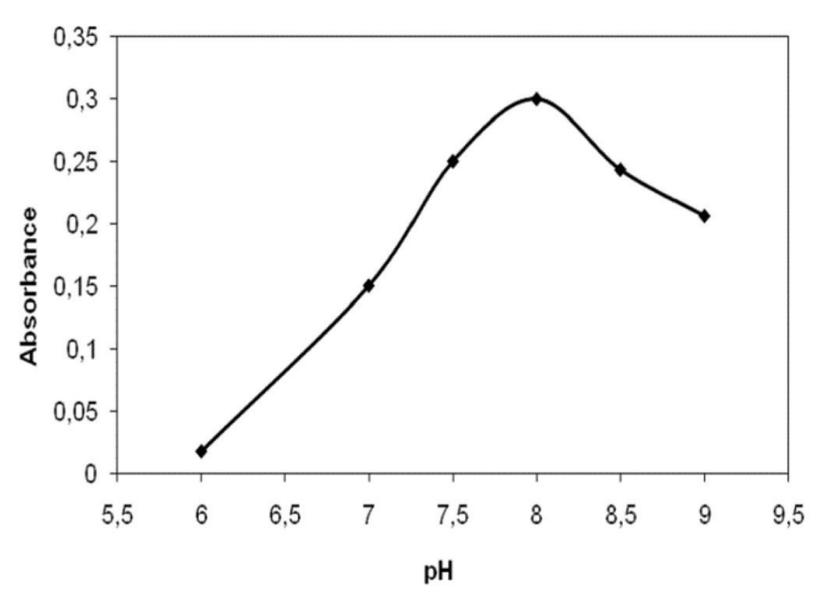

Fig. 1. Influence of $\mathrm{pH}$ on the extraction of $\mathrm{Cu}$ (II). Conditions: $[\mathrm{SPAR}]=1.4 \times 10^{-5} \mathrm{~mol} \mathrm{l}^{-1}$, $[\mathrm{Cu}]=26.5 \mu \mathrm{g} \mathrm{l^{-1 }}$, [TX$100]=0.16 \%(w / v)$ and $[\mathrm{Ph}]=0.6 \%(w / v)$.

\subsection{Effect of the SPAR concentration}

The efficiency of analyte extraction was found to be dependent on the SPAR concentration, as shown in Figure 2. The influence of the SPAR concentration on CPE extraction of $\mathrm{Cu}$ was evaluated in the concentration range of $0.6 \times 10^{-5}-1.8 \times 10^{-5} \mathrm{~mol} \mathrm{l}^{-1}$. At $1.4 \times 10^{-5} \mathrm{~mol} \mathrm{l}^{-1}$ of SPAR, extraction was found to be quantitative, hence this concentration of SPAR was used for other experiments.

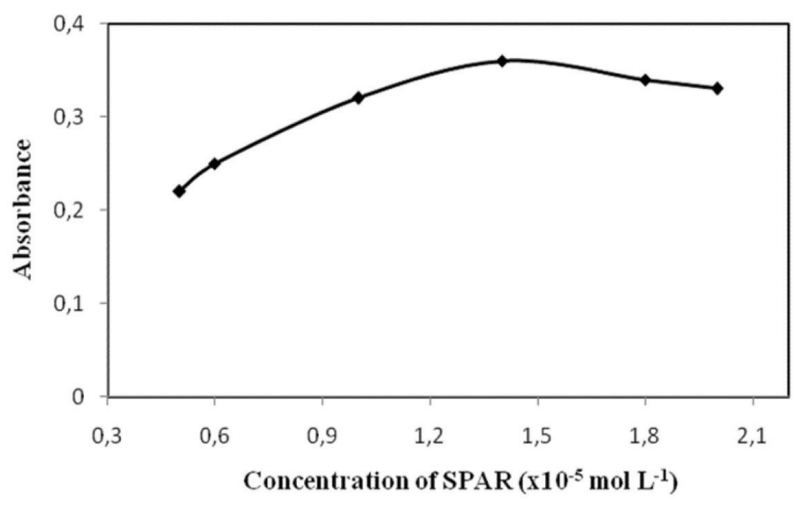

Fig. 2. Effect of SPAR concentration on the extraction of copper. Conditions: $[\mathrm{Cu}]=26.5 \mu \mathrm{g} \mathrm{l}^{-1}$, $[\mathrm{TX}-100]=0.16 \%(w / v)$, $[\mathrm{Ph}]=0.6 \%(w / v)$ and $[\mathrm{pH}]=8.0$

\subsection{Effect of the Triton $X-100$ concentration}

The effect of surfactant concentration on CPE is important. A successful cloud point extraction should maximize the extraction efficiency by minimizing the phase volume ratio $\left(V_{\text {org }} / V_{\text {aq }}\right)$, thus improving the concentration factor [22]. In this study, Triton X-100 was used as a surfactant agent. The variation in CPE extraction efficiency of $\mathrm{Cu}$ within the Triton X-100 concentration range of $0.1-0.35(w / v)$ was examined, and the results are shown in Figure 3. As can be seen, the recovery increased with the increase of Triton X-100 concentration up to $0.16 \%(w / v)$, reaching a plateau, which is considered as complete extraction. So, a concentration of $0.16 \%(w / v)$ was chosen as the optimum surfactant concentration. The preconcentration and enhancement factor decreased at higher concentrations due to an increase in the volume of the surfactant-rich phase. For this reason, the measured absorbance decreased because of its sensitivity. At lower concentrations, the extraction efficiency of the complex was low, probably because of the inadequacy of assemblies to entrap the hydrophobic complex quantitatively.

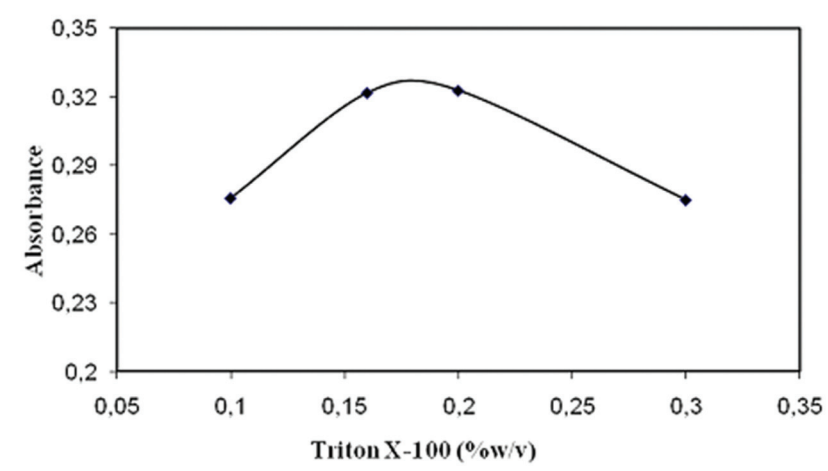

Fig. 3. Variation in the analytical signal of copper as a function of Triton X-100 concentration.

Conditions: $[\mathrm{SPAR}]=1.4 \times 10^{-5} \mathrm{~mol}^{-1},[\mathrm{Cu}]=26.5 \mu \mathrm{g}^{-1},[\mathrm{Ph}]=$ $0.6 \%(w / v)$ and $[\mathrm{pH}]=8.0$ 


\subsection{Effect of the phenol concentration}

The cloud point of micellar solutions can be controlled by the addition of salts, alcohols, non-ionic or anionic surfactants and some organic compounds (i.e. benzoic acid and xylenes) [20, 23, 25]. It was reported that by adding only $\mathrm{NaCl}$ to Triton $\mathrm{X}-100$, the cloud point was reduced to $56^{\circ} \mathrm{C}$, even for the highest electrolyte concentrations $(10 \%(w / v))$. When only sodium dodecyl sulfate was added to Triton X-100 (from 0.1 to $0.5 \% w / v$ ), the cloud point of mixtures was above $98^{\circ} \mathrm{C}$ [24]. It was observed that by adding only phenol to Triton X-100 solutions, the cloud point was reduced lower than room temperature, resulting in efficient extraction [6, 14]. Therefore, its effect in the concentration range of $0.2-0.8 \%$ phenol $(w / v)$ was studied. The optimum phenol concentration was found to be $0.6 \%(w / v)$.

\subsection{Effects of equilibration temperature and time}

In the cloud point extraction procedure, the temperature of extraction and the incubation time are very important parameters for phase separation. The dependence of extraction efficiency on equilibration temperature and time was studied within the range of $25-60{ }^{\circ} \mathrm{C}$ and 10-40 min, respectively. It was found that an equilibration time of $20 \mathrm{~min}$ and temperature of $40{ }^{\circ} \mathrm{C}$ were the optimal conditions for achieving quantitative extraction. The effect of the centrifugation time had almost no impact on micelle formation, but accelerated phase separation. The effect of centrifugation time upon on extraction efficiency was studied in the range of 5-30 min. A centrifugation time of 15 $\mathrm{min}$ at $3500 \mathrm{rpm}$ was selected, since complete phase separation occurred at the end of this period and no considerable enhancement was observed with longer times.

\subsection{Effect of the diluent}

Since the surfactant-rich phase obtained after cloud point preconcentration contains a high concentration of Triton X-100 and, at the same time, the volume obtained is rather small, $1.0 \mathrm{~mol} \mathrm{l}^{-1} \mathrm{HNO}_{3}$ in methanol was added to the surfactant-rich phase after phase separation in order to facilitate its introduction into the nebulizer of the atomic absorption spectrometer. Our results show that the optimum volume of methanol was $0.4 \mathrm{ml}$. Smaller added volumes of acidified methanol were not tested because, in this case, it was not possible to quantitatively transfer the rich phase from test tubes to graduated tubes to measure the absorbance. For larger added volumes of acidified methanol, dilution was obviously surpassed, resulting in a gradual reduction in absorbance. Hence, $0.4 \mathrm{ml}$ of $0.1 \mathrm{~mol} \mathrm{l}^{-1}$ nitric acid in methanol was used for further studies.

\subsection{Effect of diverse ions}

The effects of potential interfering cations and anions on the extraction of $\mathrm{Cu}$ were examined; the results are given in Table 1. In these experiments, solutions containing $26.5 \mu \mathrm{g}$ $\mathrm{I}^{-1}$ of $\mathrm{Cu}$ and the interfering ions were treated according to the recommended procedure. The tolerance limit was defined as the amount of foreign ions required to cause $\pm 5 \%$ error in the determination of copper. At the given level, no significant interference was observed. Copper recoveries were nearly quantitative in the presence of other cations and anions. Furthermore, these results clearly indicate the high level of selectivity of the FAAS method, and no masking reagents were required for the efficient determination of copper in water samples. 
Table 1

Tolerance limits of interfering ions

\begin{tabular}{lc}
\hline \hline Ions & Tolerance limits $\left(\mathrm{mg} \mathrm{l}^{-1}\right)$ \\
\hline $\mathrm{Na}^{+}, \mathrm{K}^{+}, \mathrm{Ca}^{2+}$ & 4000 \\
$\mathrm{Ni}^{2+}, \mathrm{Fe}^{3+}, \mathrm{Zn}^{2+}, \mathrm{Mg}^{2+}, \mathrm{Al}^{3+}, \mathrm{Cr}^{3+}, \mathrm{Cd}^{2+}, \mathrm{Co}^{2+}, \mathrm{Pb}^{2+}$ & 200 \\
$\mathrm{SO}_{4}{ }^{2-}$ & 4924 \\
$\mathrm{NO}^{-}$ & 1332 \\
$\mathrm{Cl}^{-}$ & 7087 \\
$\mathrm{PO}_{4}^{3-}$ & 900 \\
\hline \hline
\end{tabular}

\subsection{Figures of merit}

Calibration graphs were obtained by the preconcentration of $50 \mathrm{ml}$ of standard solutions in the presence of $0.16 \%$ Triton $\mathrm{X}-100$ in medium at $\mathrm{pH}$ 8.0. The samples were introduced into the flame by conventional aspiration following the addition in $0.4 \mathrm{ml}$ of $0.1 \mathrm{~mol} \mathrm{l}^{-1} \mathrm{HNO}_{3}$ methanol solution. Copper could be determined in the range of $4-450 \mu \mathrm{gl}^{-1}$ of $\mathrm{Cu}$ (II) with a correlation coefficient of 0.994 . The regression equation was $A=0.00507 \boldsymbol{c}+$ 0.001 , where $A$ is the absorbance and $c$ is the copper concentration in solution $\left(\mu \mathrm{g} \mathrm{l}^{-1}\right)$. The limit of detection (LOD), defined as $c_{\mathrm{L}}=3 S_{\mathrm{B}} / \mathrm{m}$ (where $c_{\mathrm{L}}, S_{\mathrm{B}}$, and $\mathrm{m}$ are the minimum detectable concentration, the standard deviation of the blank, and the slope of the calibration graph, respectively), was calculated to be $1.64 \mu \mathrm{g}^{-1}$ ( $n$ $=5)$. The relative standard deviation (RSD) for five replicate determinations of $12 \mu \mathrm{g} 1^{-1} \mathrm{Cu}(\mathrm{II})$ was $3.4 \%$. The enrichment factor was found to be equal to 31 . It was calculated as the ratio of the aqueous solution volume to that of the surfactant-rich volume after dilution with the methanol solution containing nitric acid.

Ta b 1 e 2

Analysis of $\mathrm{Cu}$ in various samples $(n=3)$

\begin{tabular}{lcccc}
\hline \hline Sample & $\begin{array}{c}\text { Added } \\
\left(\mu \mathrm{gl}^{-1}\right)\end{array}$ & $\begin{array}{c}\text { Found } \\
\left(\mu \mathrm{gl}^{-1}\right)\end{array}$ & $\begin{array}{c}\text { Recovery } \\
(\%)\end{array}$ & $\%$ RSD \\
\hline \multirow{3}{*}{ Rain water } & 0 & $\mathrm{nd}$ & - & 1.15 \\
& 50 & $52 \pm 0.2$ & 104 & 1.02 \\
& 110 & $107 \pm 0.4$ & 97.3 & 0.98 \\
Tap water & 0 & $5.9 \pm 0.1$ & - & 0.46 \\
& 50 & $53 \pm 0.3$ & 106 & 1.03 \\
Stream water & 100 & $102.4 \pm 0.3$ & 102.4 & 1.01 \\
& 0 & $\mathrm{nd}$ & - & 0.32 \\
& 60 & $58.3 \pm 0.2$ & 97.2 & 0.98 \\
\hline \hline
\end{tabular}

nd - Not detected 


\subsection{Application}

The analyses were performed according to the general procedure. The accuracy of the proposed method was examined by determining copper in water and certified reference material (SPSWW1 Batch 109). The certified reference material was also analyzed for copper. The analytical value $\left(\mathrm{Cu}=400 \pm 2 \mu \mathrm{g} \mathrm{l}^{-1}\right)$ was in good agreement with the certified value $\left(\mathrm{Cu}=403 \pm 4 \mu \mathrm{gl}^{-1}\right)$ for $n=5$.

In order to demonstrate the applicability of the developed procedure, tap water, stream water and rainwater were analyzed. The results are shown in Table 2. Recovery of $\mathrm{Cu}(\mathrm{II})$ was found to lie in the range of $97-104 \%$, indicating that the method enabled the determination of $\mathrm{Cu}$ in the analyzed samples.

Ta b le 3

Comparative data from some studies on CPE preconcentration of copper

\begin{tabular}{lccccc}
\hline \hline Reagent & Surfactant & PF & $\begin{array}{c}\text { Detection } \\
\text { limit } \\
\left(\mathrm{ng} \mathrm{m}^{-1}\right)\end{array}$ & Method & Reference \\
\hline $\begin{array}{l}\text { 3-((Indolin-3-yl) (phenyl) } \\
\text { methyl)indoline }\end{array}$ & Triton X-114 & 30 & 1,6 & FAAS & 26 \\
Alizarin red S & Triton X-114 & 21 & 1,07 & FAAS & 9 \\
NDTT & Triton X-114 & 22,4 & 0,22 & FAAS & 11 \\
O,O-Diethyldithiophosphate & Triton X-100 & - & 0,94 & FAAS & 7 \\
HEPTS & Triton X-114 & 5 & 0,1 & Spectrophotometric & 27 \\
Thiamine & Triton X-114 & 10 & 0,29 & Spectrofluorimetry & 28 \\
Monocarboxylic acids & OP-10 & 10 & 10 & FAAS & 29 \\
Without ligand & Tween 80 & 10 & 0,4 & FAAS & 30 \\
SPAR & Triton X-100 & 31 & 1,64 & FAAS & This work \\
\hline \hline
\end{tabular}

PF: Preconcentration factor

\section{CONCLUSION}

The synthesis of SPAR in the laboratory was simple and economical. The ligand used as a complexing agent showed excellent complexing ability with copper in CPE using Triton X-100. The surfactant-rich phase could be introduced into the nebulizer of the FAAS after dilution with acidified methanol. The main advantages of the method are simplicity, low cost, excellent safety and good extraction efficiency. The results of this study showed that the combination of CPE and FAAS were beneficial and provided a valid method for the highly selective determination of copper. Table 3 shows a comparison of the method described in this work with those found in the literature. The accuracy of the method was assessed through recovery experiments, reference material and real samples at $\mu \mathrm{g} 1^{-1}$ levels. This procedure is a good alternative for the accurate determination of copper in environmental water samples.

Acknowledgments. The authors would like to thank Cevat Tunç for the synthesis of SPAR.

\section{REFERENCES}

[1] J. M. Neff, Bioaccumulation in Marine, Elsevier, San Diego, 2002.

[2] F. W. Oehme, Toxicity of Heavy Metals in the Environment, Marcel Dekker, New York, 1978.

[3] J. M. Moore, Inorganic Contaminants of Surface Water, Springer Verlag, New York, 1991.

[4] S. Tascioglu, Micellar Solutions As Reaction Media, Tetrahedron, 52, 11113-11152 (1996). 
[5] Z. S. Ferrera, C. P. Sanz, C. M. Santana, J. J. S. Rodriguez, The use of micellar systems in the extraction and pre-concentration of organic pollutants in environmental samples, Trends Anal. Chem., 23, 469-479 (2004).

[6] B. M. De Almeida, M. A. Z. Arruda, S. L. C. Ferreira, Cloud point extraction as a procedure of separation and pre-concentration for metal determination using spectroanalytical techniques: A review, Appl. Spectrosc. Rev., 40, 2690299 (2005).

[7] J. L. Manzoori, A. Bavili-Tabrizi, The application of cloud point preconcentration for the determination of $\mathrm{Cu}$ in real samples by flame atomic absorption spectrometry, Microchem. J., 72, 1-7 (2002).

[8] M. Ghaedi, A. Shokrollahi, K. Niknam, M. Soylak, Cloud point extraction of copper, zinc, iron and nickel in biological and environmental samples by flame atomic absorption spectrometry, Sep. Sci. Technol., 44, 773-786 (2009).

[9] N. Satiroglu, C. Arpa, Cloud point extraction for the determination of trace copper in water samples by flame atomic absorption spectrometry, Microchim. Acta, 162, 107-112 (2008).

[10] N. Goudarzi, Determination of trace amounts of copper in river and sea water samples by flame atomic absorption spectrometry (FAAS) after cloud-point preconcentration, J. Braz. Chem. Soc., 18, 1348-1352 (2007).

[11] P. Biparva, M. R. Hadjmohammadi, Cloud point extraction using NDTT reagent for preconcentration and determination of copper in some environmental water samples by flame atomic absorption spectroscopy, Acta Chim. Slov., 54, 805-810 (2007).

[12] N. Dalali, N. Javadi, K.Y. Agrawal, On-line incorporation of cloud point extraction in flame atomic absorption spectrometric determination of silver, Turk. J. Chem., 32, 561-570 (2008).

[13] J. Chen, K. C. Teo, Determination of cadmium, copper, lead and zinc in water samples by flame atomic absorption spectrometry after cloud point extraction, Anal. Chim. Acta, 450, 215-222 (2001).

[14] R. K. Mahajan, K. K. Vohra, N. Kaur, V. K. Aswal, Organic additives and electrolytes as cloud point modifiers in octylphenol ethoxylate solutions, $J$. Surfactants Deterg., 11, 243-250 (2008).

[15] H. Filik, Z. Yanaz, R. Apak, Selective determination of total vanadium in water samples by cloud point extraction of its ternary complex, Anal. Chim. Acta, 620, 27-33 (2008).
[16] F. Dondurmacioglu, H. Filik, Application of a ternary complex of chromium(VI) with phenylfluorone for cloud point extraction-spectrophotometric speciation of $\mathrm{Cr}(\mathrm{VI})$ and $\mathrm{Cr}(\mathrm{III})$ in aqueous solutions, J. Anal. Chem., 64, 455-461 (2009).

[17] M. Soylak, Y. E. Unsal, Double-walled carbon nanotubes as a solid phase extractor for separationpreconcentration of traces of gold from geological and water samples, Int. J. Environ. Anal. Chem., 91, 440-447 (2011).

[18] J. K. Armstrong, B. Z. Chowdhry, M. J. Snowden, S.A. Leharne, Effect of sodium chloride upon micellization and phase separation transitions in aqueous solutions of triblock copolymers: A highsensitivity differential scanning calorimetry study, Langmuir, 14, 2004-2010 (1998).

[19] G. Komaromy-Hiller, N. Calkins, R. von Wandruszka, Changes in polarity and aggregation number upon clouding of a nonionic detergent: effect of ionic surfactants and sodium chloride, Langmuir, 12, 916-920 (1996).

[20] T. Gu, P. Galera-Gomez, The effect of different alcohols and other polar organic additives on the cloud point of Triton X-100 in water, Colloids Surf. A, 147, 365-370 (1999).

[21] H. İ. Ulusoy, M. Akçay, R. Gürkan, Development of an inexpensive and sensitive method for the determination of low quantity of arsenic species in water samples by CPE-FAAS, Talanta, 85, 15851591 (2011).

[22] E. K. Paleologos, D. L. Giokas, M. I. Karayannis, Micelle-mediated separation and cloud-point extraction, Trends Anal. Chem., 24, 426-436 (2005).

[23] C. D. Stalikas, Micelle-mediated extraction as a tool for separation and preconcentration in metal analysis, Trends Anal. Chem., 21, 343-355 (2002).

[24] C. C. Nascentes, M. A. Z. Arruda, Cloud point formation based on mixed micelles in the presence of electrolytes for cobalt extraction and preconcentration, Talanta, 61, 759-768 (2003).

[25] N. Pourreza, S. Elhami, Spectrophotometric determination of malachite green in fish farming water samples after cloud point extraction using nonionic surfactant Triton X-100, Anal. Chim. Acta, 596, 62-65 (2007).

[26] M. Ghaedi, A. Shokrollahi, K. Niknam, E. Niknam, M. Soylak, Development of efficient method for preconcentration and determination of copper, nickel, zinc and iron ions in environmental samples by combination of cloud point extraction 
and flame atomic absorption spectrometry, Cent. Eur. J. Chem., 7(1), 148-154 (2009).

[27] M. M. Hassanien, M. H. Abdel-Rhman, A. A. ElAsmy, Cloud point extraction and spectrophotometric determination of $\mathrm{Cu}(\mathrm{II})$ in saturated saline solutions using 4-ethyl-1-(pyridin-2-yl)thiosemicarbazide, Transition Met. Chem, 32, 1025-1029 (2007).

[28] B. Tabrizi, Development of a cloud point extraction-spectrofluorimetric method for trace copper(II) determination in water samples and parenteral solutions, J. Hazard. Mater., 139, 260-264 (2007).
[29] S. A. Kulichenko, V. O. Doroschuk, S. O. Lelyushok, The cloud point extraction of copper(II) with monocarboxylic acids into non-ionic surfactant phase, Talanta, 59, 767-773 (2003).

[30] S. Candir, I. Narin, M. Soylak, Ligandless cloud point extraction of $\mathrm{Cr}(\mathrm{III}), \mathrm{Pb}$ (II), $\mathrm{Cu}$ (II), $\mathrm{Ni}$ (II), $\mathrm{Bi}(\mathrm{III})$, and $\mathrm{Cd}(\mathrm{II})$ ions in environmental samples with Tween 80 and flame atomic absorption spectrometric determination, Talanta, 77, 289-293 (2008). 